ORIGINAL RESEARCH PAPER

\title{
EFFECT OF HEAT PROCESSING ON THE NUTRITIONAL AND ANTI- NUTRITIONAL FACTORS OF COWPEA (Vigna unguiculata)
}

\author{
VIRUSKA JAICHAND ${ }^{1}$, DEPIKA DWARKA ${ }^{1}$, ABE SHEGRO GERRANO ${ }^{2}$ AND JOHN JASON \\ MELLEM $^{1 *}$
}

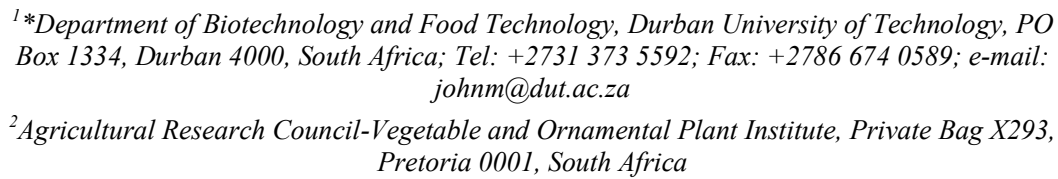

\begin{abstract}
Nutritionally enhanced cowpea genotypes provide considerable amounts of nutritional composition, which are useful to tackle nutritional deficiency status among rural and urban populations. However, the presence of anti-nutritional factors reduces the availability and absorption of nutrients, particularly of important micronutrients for growth and development. Therefore, the aim of this study was to assess the response of different processing method that allows availability of maximum nutrients in the seeds of test cowpea cultivars. Results showed that soaked cowpea samples had the lowest nutritional content and greatest anti-nutritional content. Boiling allowed for an improved protein content (19-21\%) and was the most effective in reducing cyanogenic glycosides $(0.18-0.38 \mathrm{mg} / 100 \mathrm{~g})$, phytic acid $( \pm 1.21 \mathrm{mg} / 100 \mathrm{~g})$, tannins $(0 \mathrm{mg} / 100 \mathrm{~g})$ and trypsin inhibitors $(55-155 \mathrm{TIU} / \mathrm{g})$. While, autoclaving was the most effective in reducing the oxalic acid $( \pm 2 \mathrm{mg} / 100 \mathrm{~g})$ content based on the presence of water-insoluble oxalic acid.
\end{abstract}

Keywords: Vigna unguiculata, proximate composition, anti-nutritients

\section{Introduction}

Cowpea has been disbursed as an important food legume in Africa for over 6 thousand years. As time has passed, it has slowly become a part of the diets of people around the world, with an estimated global production of approximately 12.5 million tons per year (FAO, 2018) of which the total grain production for human consumption is only 7.2 million tons. Despite cowpea having the potential to increase the nutrient profile of diets of low-income households, there are constraints associated with the utilization of cowpea as a food legume due to the

https://doi.org/10.35219/foodtechnology.2020.1.10 
presence of anti-nutritional factors. Anti-nutritional factors refer to specific components that can be poisonous to the human body.

These anti-nutritional factors are basically molecular compounds synthesized into secondary metabolites by species that are sedentary in nature (plants, bacteria and fungi) (Bora, 2014). Constant consumption of these metabolites can lead to toxin build up which at elevated levels lead to adverse health effects. Ingestion of these metabolites results in an impairment of normal metabolism and limited digestion of essential nutrients in the body. It is therefore imperative that these anti-nutritional factors are reduced or completely removed/inactivated to prevent such adversities. In order to improve the overall nutritional content, various processing methods can be applied to either reduce or completely remove anti-nutritional factors that are present in legumes (Akande and Fabiyi, 2010).

It has been found that the nutritive value of certain legumes improves after conducting heat treatments. These heat treatments are usually prior to consumption (Sathe et al., 1984). Wet heat has been proven to be more effective than dry heat (Bressani and Sosa, 1990; Omenna et al., 2016). Boiling (cooking) is often used to eliminate volatile and heat-labile anti-nutritional factors such as trypsin inhibitors. Trugo et al. (1990), found that approximately $30-40 \%$ of polyphenols and around $90 \%$ of trypsin inhibitors can be removed from Phaseolus vulgaris after boiling. The process of autoclaving uses a stream that is under pressure to cook foods allowing for reduced cooking time. Udedibie and Nwaiwu (1988), reported the complete inactivation of cyanogenic glycosides, alkaloids, saponins as well as terpenoids when processed for $125^{\circ} \mathrm{C}$ at a pressure of $15 \mathrm{lb}$. Soaking is the least labour intensive and inexpensive processing method affordable for resource poor communities. It allows for the leaching of anti-nutritional factors into the solution used during the soaking process. However, some of the constituents are affected when metabolic reactions occur. It was noted by Desphande and Cheryan (1983); Dhurandhar and Chang (1990), as well as Trugo et al. (1990), that soaking resulted in no major reductions in trypsin inhibitor contents in $P$. vulgaris. The availability of a high antinutritional content in cowpea may not be good for consumption due to its negative impact on nutrient availability and digestibility unless processed using different processing techniques. Therefore, this study was carried out to look at the comparative effect of different heat processing methods on the nutritional and antinutritional content of four Vigna unguiculata cultivars, in order to identify a process which would allow the maximum reduction of anti-nutrients for human consumption.

\section{Materials and methods}

\section{Sample Preparation}

Four cowpea cultivars (Bechuana White, TUV 11424, Pan 311 and Fahari) were obtained from the Agricultural Research Council, South Africa. The seeds were cleaned and sorted to remove extraneous matter. The cowpea cultivars were then subjected to the following pretreatments: 
Soaking: cowpea cultivars were soaked overnight in distilled water at room temperature (with a ratio of 1:5 m/v). Once the pretreatment had been completed, the distilled water was decanted, and the cultivars were divided into three equal portions $(33.33 \mathrm{~g})$. The processed cowpea cultivars were dried overnight at $50^{\circ} \mathrm{C}$ and thereafter milled into a flour.

Autoclaving: seeds $(33.3 \mathrm{~g})$ were autoclaved at $121^{\circ} \mathrm{C}$ for $10 \mathrm{~min}$. The processed cowpea cultivars were dried overnight at $50^{\circ} \mathrm{C}$ and thereafter milled into a flour.

Boiling: pretreated samples were boiled in distilled water (a ratio of 1:15 w/v) for $30 \mathrm{~min}$. After boiling, the liquid was decanted, and processed seeds dried overnight at $50^{\circ} \mathrm{C}$ and thereafter milled into a flour.

\section{Nutritional_Analysis}

Proximate composition analysis was conducted to measure moisture, protein $(\mathrm{N} \times 6.25)$, fat, ash, crude fibre and carbohydrate (by difference) in triplicate, according to the Association of Official Analytical Chemists (AOAC) standard procedures (AOAC, 2012).

\section{Anti-nutritional Analysis}

\section{Tannin}

Sample $(0.5 \mathrm{~g})$ was added to $50 \mathrm{~mL}$ of distilled water and placed on a shaker for 1 $\mathrm{h}$ at $230 \mathrm{rpm}$ (Van-Buren and Robinson, 1969). Samples were then filtered using a Whatman no. 1 filter paper and $2 \mathrm{~mL}$ of the tannin's reagent $\left(0.1 \mathrm{M} \mathrm{FeCl}_{3}\right.$ in $0.1 \mathrm{~N}$ $\mathrm{HCl}$ and $0.008 \mathrm{M}$ potassium ferrocyanide) added to $5 \mathrm{~mL}$ of the filtrate. The absorbance was read at $605 \mathrm{~nm}$ within $5 \mathrm{~min}$ on a spectrophotometer (Thermo Scientific Genesys 30 visible spectrophotometer). A standard curve, dilutions of $10-50 \mathrm{mg} / 5 \mathrm{~mL}$ tannic acid, was used to determine tannin content.

Trypsin inhibitor

Sample $(1 \mathrm{~g})$ was added to $50 \mathrm{~mL}$ of $0.5 \mathrm{M} \mathrm{NaCl}$ and allowed to stir for $30 \mathrm{~min}$ at $200 \mathrm{rpm}$ (Inuwa et al., 2011). Samples were then centrifuged (1500 rpm for $5 \mathrm{~min}$ at $20^{\circ} \mathrm{C}$ ). The supernatant was filtered, with the filtrate (substrate) read at $410 \mathrm{~nm}$.

Thereafter, $2 \mathrm{~mL}$ of the standard trypsin solution was added to $10 \mathrm{~mL}$ of the substrate, vortexed and read at $410 \mathrm{~nm}$. Trypsin inhibition (mg of trypsin inhibited per $g$ of sample) was calculated using the following equation:

$$
\text { Trypsin inhibition }=\frac{(A) \times(B)}{\text { weight of sample }(g)}
$$

A: Absorbance of blank - Absorbance of blank with standard trypsin solution

B: Dilution of sample

\section{Phytate}

Briefly, $10 \mathrm{~mL}$ of $2.4 \% \mathrm{HCl}$ was added to $10 \mathrm{~g}$ of sample, placed on a mechanical shaker at $220 \mathrm{rpm}$ for $16 \mathrm{~h}$ and centrifuged at $1000 \mathrm{x} \mathrm{g}$ for $20 \mathrm{~min}$ (Gao et al., 2007). The resultant supernatant was transferred to centrifuge tubes containing $1 \mathrm{~g}$ of $\mathrm{NaCl}$, placed on a mechanical shaker $(350 \mathrm{rpm}, 20 \mathrm{~min})$ and centrifuged. One milliliter of the clear supernatant was diluted $\left(24: 1, \mathrm{dH}_{2} \mathrm{O}\right.$ : supernatant). One 
milliliters of wades reagent $\left[\left(0.03 \% \mathrm{FeCl}_{3} .6 \mathrm{H}_{2} \mathrm{O}\right)-30 \mathrm{mg}\right.$ and $0.3 \%$ sulfosalicyclic acid $(300 \mathrm{mg}$ ) made up to $100 \mathrm{~mL}$ ] was added to $3 \mathrm{~mL}$ of diluted sample, centrifuged $\left(1000 \mathrm{x} g\right.$ for $10 \mathrm{~min}$ at $\left.10^{\circ} \mathrm{C}\right)$ and the absorbance read at $500 \mathrm{~nm}$. For the standard curve, phytate was diluted to different concentrations of 10-50 $\mu \mathrm{L} / 3$ $\mathrm{mL}$, followed by the addition of wades reagent. The amount of phytic acid present in the sample was determined using the standard curve and thereafter placed into the following equation:

$$
\text { Phytate (mg per } 100 \mathrm{~g} \text { of sample) }=\frac{\mathrm{Fe}(\mu \mathrm{g}) \times 15}{0.500}
$$

\section{Cyanogenic glucosides}

Cowpea sample $(2.5 \mathrm{~g})$ was added to $25 \mathrm{~mL}$ of distilled water and allowed to extract overnight and filtered (Onwuka, 2005). To $1 \mathrm{~mL}$ of the filtrate, $4 \mathrm{~mL}$ of alkaline picrate solution was added $(1 \mathrm{~g}$ picrate and $5 \mathrm{~g}$ of sodium carbonate made up to $200 \mathrm{~mL}$ ), incubated in a water bath at $100^{\circ} \mathrm{C}$ for $15 \mathrm{~min}$ and the absorbance read on a spectrophotometer at $490 \mathrm{~nm}$. For the standard curve, potassium cyanide was diluted to different concentrations $(10-50 \mu \mathrm{L} / \mathrm{mL})$ with the following equation used to calculate the amount of cyanogenic glucoside $(\mathrm{mg} / 100 \mathrm{~g})$ :

Cyanogenic glycoside $=\frac{\text { Concentration of cyanide read off standard curve }(\mathrm{mg}) \times 10}{\text { Weight of sample }}$

\section{Oxalic acid}

Samples $(0.5 \mathrm{~g})$ were added to $30 \mathrm{~mL}$ of $0.25 \mathrm{~N} \mathrm{HCl}$ and was placed in a water bath $\left(15 \mathrm{~min}, 100^{\circ} \mathrm{C}\right)$ (Naik et al., 2014). The samples were then made up to $50 \mathrm{~mL}$ with $0.25 \mathrm{~N} \mathrm{HCl}$. One milliliter of sample was then added to $5 \mathrm{~mL}$ of $2 \mathrm{~N} \mathrm{H}_{2} \mathrm{SO}_{4}$ and $2 \mathrm{~mL}$ of $0.003 \mathrm{M} \mathrm{KMnO}_{4}$. These were then incubated at room temperature (10 min) and read at $528 \mathrm{~nm}$ on a spectrophotometer. The blank consisted of $1 \mathrm{~mL}$ of distilled water and $5 \mathrm{~mL}$ of $2 \mathrm{~N} \mathrm{H}_{2} \mathrm{SO}_{4}$ as well as $0.003 \mathrm{M} \mathrm{KMnO}_{4}$. The amount of oxalic acid present in the sample was determined by a standard curve. For the standard curve, oxalic acid was prepared with distilled water $(1 \mathrm{mg} / \mathrm{mL})$. Two milliliters of $0.003 \mathrm{M}$ potassium permanganate and $5 \mathrm{~mL}$ of $2 \mathrm{~N}$ sulfuric acid was added. The sample was then incubated $(10 \mathrm{~min})$ and read at an absorbance of 528 nm.

\section{Statistical Analysis}

To evaluate the differences, two-way analysis of variance, ANOVA (Graph Pad Prism), followed by Bonferroni post-tests was carried out, with values expressed as mean \pm standard deviation $(\mathrm{p}<0.05)$.

\section{Results and discussion}

\section{Nutritional analysis}

The moisture content of food products is known to affect safety, quality and the shelf-life of a product (Appoldt and Raihani, 2017). The current results showed that there were significant differences among heated treated samples. It was established that heat-treated samples resulted in higher moisture content than the 
soaked cowpea samples (Table 1). This is probably due to the heat processing methods requiring the use of boiling water/steam under pressure, which results in moisture remaining in the sample. Overall, it was found that processing had a nonsignificant effect on moisture content of the four cowpea cultivars. The autoclaved samples had the most moisture content ranging between 14-20\%, with Fahari exhibiting the highest. These results are line with studies by Giami, (1993), who showed heat-treated (autoclaved) samples to have a greater moisture content than raw samples. Other studies by Onyeike and Omubo-Dede (2002) correlates to the data obtained in this study, where autoclaved African yam bean (Sphenostylis stenocarpa) varieties had a greater moisture content than boiled and raw samples. Omenna et al. (2016) found that boiled samples had the greatest moisture content $(15.14 \%)$, followed by pressure cooked samples $(11.07 \%)$ with raw samples having the lowest moisture content (3.80\%).

Ash content represents the total mineral content in a sample. The samples that were heat-treated (boiled and autoclaved) had an overall lower ash content than samples that had only been soaked. No significant difference was noted between the cultivars. Soaked samples had an ash content of approximately $4 \%$. Both boiled and autoclaved samples ranged from 3-4\%. These findings are in line with results obtained by El-Adaway (2002), Giami (1993) and Ommena et al. (2016). Nell and Siebrits (1992) had also reported an ash content ranging around 3\% for raw and autoclaved cowpea meals. It can consequently be stated that processing does not contribute to a major change in the ash percentages.

Fats are an important energy source to the human body (Jéquier, 1994). It was noted that processing had a significant effect on the fat content of the four cowpea cultivars. All soaked cultivars had a low-fat content in comparison to boiled and autoclaved samples. Boiled samples had the highest fat content with Fahari being greatest $(44.06 \%)$. These findings are similar to the findings reported by ElAdaway (2002), who identified boiled samples to have a greater fat content than autoclaved samples.

Autoclaved cowpea meals were found to have greater fat content than raw-cowpea meals in a study conducted by Nell and Siebrits (1992), which is in agreement with the data reported in Table 1. Trugo et al. (2000) also reported a higher fat content in heat treated legume seeds. It is theorized that the boiling process affects the structures, thus allowing for a greater quantity of fat to be extracted. This contrasts with Giami (1992), who found that the fat content had remained the same for raw and heat-treated samples $(1.7 \%)$.

Generally, processing had a significant effect on protein content with soaked samples producing the least amount of protein (16-20\%), followed by autoclaved (26-17\%). A higher protein content in autoclaved samples can be attributed to heat inactivating certain anti-nutrients (Trugo et al., 2000). This is contradictory to Drulyte and Orlien (2019), who found that autoclaving of legumes significantly reduced the content of crude proteins compared to the raw legumes. Boiled samples showed the highest protein percentage (19-21\%). Across all processing methods Fahari contained the highest content of protein. Nell and Siebrits (1992), 
also found a higher protein content in autoclaved cowpea meal than in raw cowpea meal. EL-Adaway (2002) also found results that were in line with this study. Leaching of anti-nutrients into the water utilized during the boiling process coupled with heat is a possible reason for boiled samples containing a greater protein content than autoclaved samples. In contrast, Giami (1992) discovered that raw, germinated and fermented flour samples had a crude protein ranging around $24 \%$ in comparison to heat-treated flour samples which had a lower crude protein $(22.7 \%)$.

Carbohydrates play a primary role in providing energy and contributes to dietary fibre in the human diet (Slavinn and Carlson, 2014). The carbohydrate content in this study was the highest in the soaked cowpea samples (58.04\%). It was deduced that heat treatments reduced the carbohydrate content as boiled samples presented a carbohydrate content of $24.16 \%$ and autoclaving resulted in a carbohydrate content of $26.60 \%$. This deduction is in accordance with the study by Apata (2008) who concluded that the application of heat results in starch gelatinization which leads to a reduced carbohydrate content. Studies by Giami (1993), found that heat-treated (autoclaved) samples had a lower carbohydrate content than raw samples. Studies by Ommena et al. (2016) showed that boiling had a greater impact in reducing the carbohydrate content than pressure cooking.

Table 1. Nutritional profile of Vigna unguiculata cultivars subjected to different processing parameters

\begin{tabular}{lccccc}
\hline & & Bechuana White & TUV 11424 & Pan311 & Fahari \\
\hline \multirow{4}{*}{ Moisture (\%) } & Soaked & $13.11 \pm 0.75^{\mathrm{a}}$ & $10.89 \pm 1.32^{\mathrm{a}}$ & $12.78 \pm 0.63^{\mathrm{a}}$ & $14.40 \pm 0.62^{\mathrm{ab}}$ \\
& Boiled & $18.04 \pm 2.67^{\mathrm{a}}$ & $15.57 \pm 2.46^{\mathrm{a}}$ & $15.99 \pm 2.07^{\mathrm{a}}$ & $16.27 \pm 1.26^{\mathrm{a}}$ \\
& Autoclaved & $14.94 \pm 0.91^{\mathrm{a}}$ & $21.10 \pm 0.48^{\mathrm{c}}$ & $16.26 \pm 0.26^{\mathrm{ab}}$ & $20.42 \pm 2.14^{\mathrm{cab}}$ \\
\hline \multirow{4}{*}{ Ash (\%) } & Soaked & $4.35 \pm 0.41^{\mathrm{a}}$ & $4.34 \pm 0.27^{\mathrm{a}}$ & $4.42 \pm 0.29^{\mathrm{a}}$ & $4.62 \pm 0.30^{\mathrm{a}}$ \\
& Boiled & $4.05 \pm 0.18^{\mathrm{a}}$ & $3.31 \pm 0.29^{\mathrm{b}}$ & $3.18 \pm 0.08^{\mathrm{ca}}$ & $3.59 \pm 0.17^{\mathrm{a}}$ \\
& Autoclaved & $3.81 \pm 0.21^{\mathrm{a}}$ & $4.30 \pm 0.07^{\mathrm{b}}$ & $4.04 \pm 0.01^{\mathrm{a}}$ & $4.13 \pm 0.20^{\mathrm{a}}$ \\
\hline \multirow{4}{*}{ Fat (\%) } & Soaked & $0.74 \pm 0.02^{\mathrm{a}}$ & $0.53 \pm 0.07^{\mathrm{a}}$ & $23.91 \pm 2.85^{\mathrm{c}}$ & $1.65 \pm 0.07^{\mathrm{ac}}$ \\
& Boiled & $30.57 \pm 0.69^{\mathrm{a}}$ & $34.59 \pm 0.70^{\mathrm{b}}$ & $29.54 \pm 0.69^{\mathrm{ac}}$ & $44.06 \pm 0.77^{\mathrm{c}}$ \\
& Autoclaved & $33.98 \pm 0.67^{\mathrm{a}}$ & $30.56 \pm 0.16^{\mathrm{b}}$ & $37.24 \pm 0.55^{\mathrm{bc}}$ & $20.75 \pm 0.91^{\mathrm{c}}$ \\
\hline \multirow{4}{*}{ Protein (\%) } & Soaked & $16.13 \pm 0.06^{\mathrm{a}}$ & $17.10 \pm 0.18^{\mathrm{a}}$ & $17.84 \pm 0.25^{\mathrm{ba}}$ & $20.26 \pm 0.72^{\mathrm{c}}$ \\
& Boiled & $19.17 \pm 0.11^{\mathrm{a}}$ & $21.01 \pm 0.18^{\mathrm{b}}$ & $20.18 \pm 0.49^{\mathrm{ab}}$ & $21.22 \pm 0.31^{\mathrm{c}}$ \\
\hline \multirow{2}{*}{$\begin{array}{l}\text { Carbohydrates } \\
(\%)\end{array}$} & Autoclaved & $17.42 \pm 0.23^{\mathrm{a}}$ & $19.76 \pm 0.41^{\mathrm{b}}$ & $19.28 \pm 0.07^{\mathrm{b}}$ & $26.32 \pm 0.91^{\mathrm{c}}$ \\
\hline & Soaked & $65.88 \pm 0.24^{\mathrm{a}}$ & $66.59 \pm 1.66^{\mathrm{a}}$ & $41.23 \pm 2.89^{\mathrm{c}}$ & $58.45 \pm 0.71^{\mathrm{c}}$ \\
& Boiled & $26.75 \pm 0.06^{\mathrm{a}}$ & $24.27 \pm 0.85^{\mathrm{a}}$ & $29.97 \pm 1.66^{\mathrm{ab}}$ & $15.63 \pm 0.54^{\mathrm{c}}$ \\
& Autoclaved & $29.34 \pm 0.05^{\mathrm{a}}$ & $24.58 \pm 0.42^{\mathrm{b}}$ & $23.16 \pm 0.99^{\mathrm{ca}}$ & $29.32 \pm 3.36^{\mathrm{abc}}$ \\
\hline
\end{tabular}

Data denotes mean \pm standard deviation $(\mathrm{n}=3)$. Values with different superscript letters are significantly different $(\mathrm{p}<0.05)$ 


\section{Anti-nutritional analysis}

\section{Tannins}

Tannins are bitter polyphenols (astringent) that are present in plants can either precipitate as well as bind or shrink proteins (Samtiya et al., 2020). Soaked cultivars had the highest tannin content ranging from 16-23 mg/100 $\mathrm{g}$ (Figure 1). Autoclaving had a decreased tannin content $(4-11 \mathrm{mg} / 100 \mathrm{~g})$, whereas boiling resulted in the complete removal of tannins. This result is in agreement with findings from the studies reported by Ommena et al. (2016) who found boiling to be more effective in reducing tannin content and Udensi et al. (2007) who showed that boiling of legumes were most effective in reducing overall tannin content. The findings of Avanza et al. (2013) found that the application of heat during processing (cooking and autoclaving) reduced the overall tannin content. These researchers conjectured that the reduction of tannins could be attributed to the diffusion of tannins when the samples were soaked as well as the tannins had bound with proteins and other substances which were organic in nature.

Nell and Siebrits (1992) investigated the nutritional content of various cowpea cultivars, and noted that autoclaving was the processing method which led to a reduction of the tannin content (lowered from $0.32 \%$ to $0.24 \%$ ). Moreover, ELAdaway (1992) found that autoclaving was the most effective in removing tannins, followed by boiling.

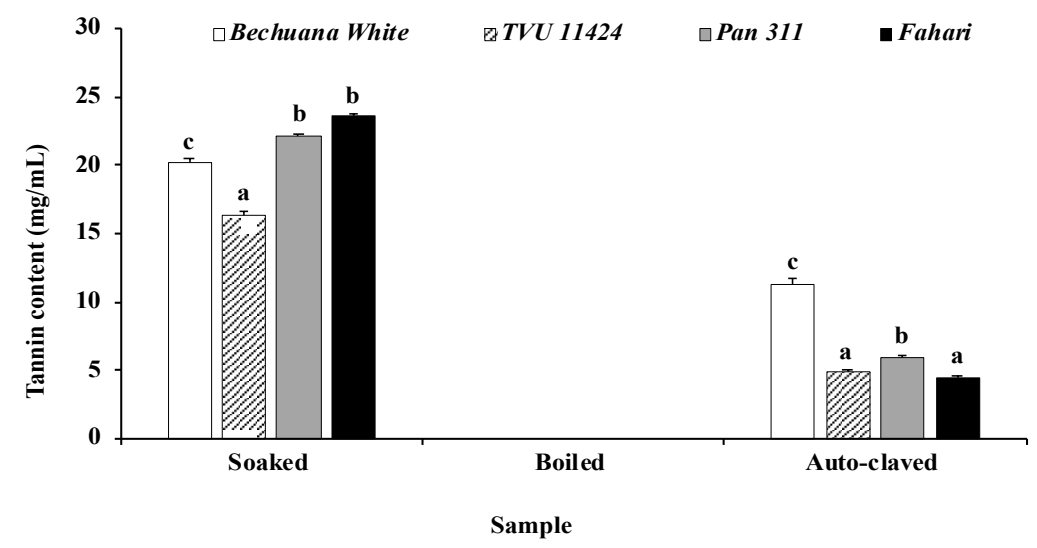

Figure 1. Effect of processing methods (soaked, boiled \& autoclaved) on tannin content of cowpea cultivars [Bars denote mean \pm standard deviation $(\mathrm{n}=3)$ ]. Values with different superscript letters are significantly different $(\mathrm{p}<0.05)$.

\section{Trypsin inhibitors}

In the gut, the presence of trypsin inhibitors in foods prevent the digestion of protein by affecting the activity of enzymes (Hill, 2003). Soaked cowpea samples had the highest trypsin inhibitor content (550-730 TIU/g), with soaked Pan 311 exhibiting the greatest concentration of trypsin inhibitors $(730 \mathrm{TIU} / \mathrm{g})$, followed by autoclaved samples (55-155 TIU/g) (Figure 2). Boiled Bechuana White had the 
lowest trypsin inhibitor content (10 TUI/g). Nell and Siebrits (1992), noted a 79\% decrease in trypsin inhibitor activity in autoclaved cowpea meal in comparison to the raw cowpea meal. A study conducted by Udensi et al. (2007), found that autoclaving for $45 \mathrm{~min}$ was effective in completely removing trypsin inhibitors. Ommena et al. (2016) found that the boiling method is most effective in reducing the trypsin inhibitors present followed by pressure cooking. EL-Adaway (1992) found that autoclaving was more effective than boiling. Shi et al. (2017) showed that there was a $78.7-100 \%$ reduction in trypsin inhibitors after the cooking of seeds that were presoaked.

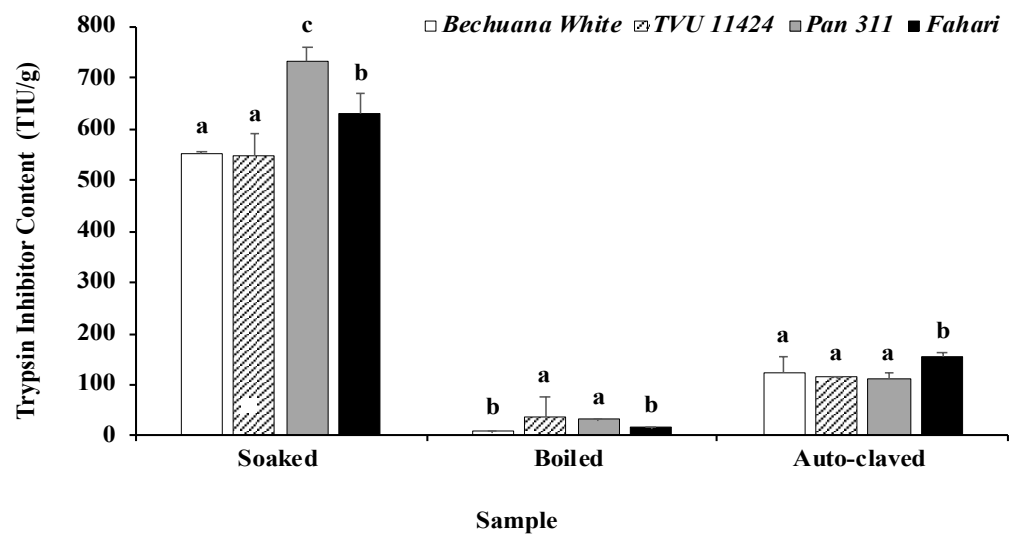

Figure 2. Effect of processing methods (soaked, boiled \& autoclaved) on trypsin inhibitor content of cowpea cultivars [Bars denote mean \pm standard deviation $(n=3)$ ]. Values with different superscript letters are significantly different $(\mathrm{p}<0.05)$.

\section{Phytate (phytic acid)}

According to a report by Samtiya et al. (2020), phytic acid hinders the activity of enzymes, which are necessary for protein degradation in the small intestine and stomach. Boiled cowpea samples had the lowest phytic acid content $( \pm 1.21 \mathrm{mg} / 100$ g) compared to soaked $(1.30 \mathrm{mg} / 100 \mathrm{~g})$ and autoclaved samples $(1.31 \mathrm{mg} / 100 \mathrm{~g})$ (Figure 3). Boiled Bechuana White $(1.11 \mathrm{mg} / 100 \mathrm{~g})$ had the least phytic acid present. A study by El-Adaway (1992) found that autoclaved samples had a greater effect than boiled chickpea samples. In contrast, Udensi et al. (2007) found that boiling for $60 \mathrm{~min}$ led to the greatest loss of phytic acid when compared to autoclaved samples. Ommena et al. (2016) found that pressure-cooking the samples resulted in lower phytate percentage of cowpea flour. Shi et al. (2018) found that both soaking and cooking did not reduce the phytic acid content in common beans, however, it was reduced in lentils, chickpeas, and peas. Samtiya et al. (2020) stated that soaking of legumes was found to be effective in enhancing the minerals concentration and protein availability, accompanied by reductions in phytic acid level. 


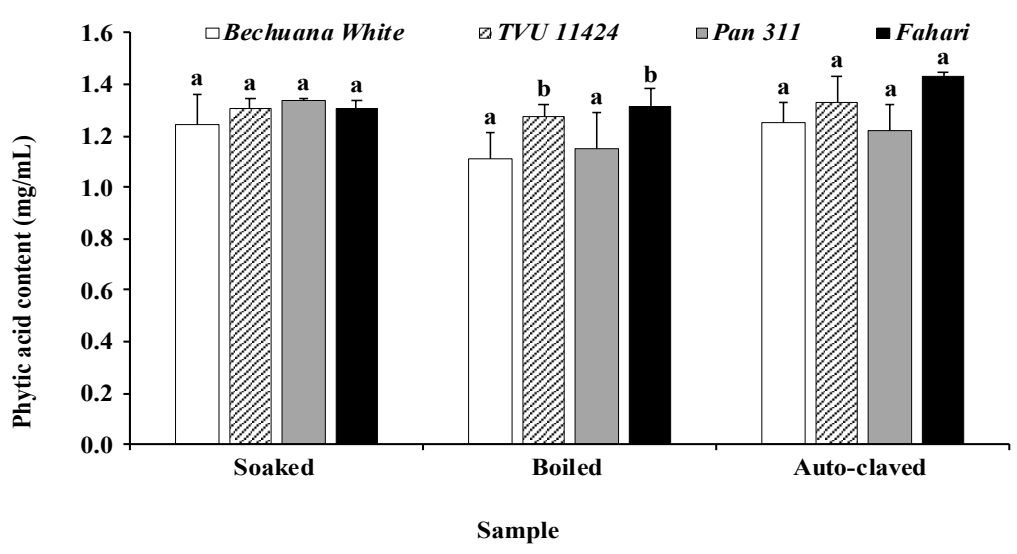

Figure 3. Effect of processing methods (soaked, boiled \& auto-claved) on phytic acid content of cowpea cultivars [Bars denote mean \pm standard deviation $(n=3)$ ]. Values with different superscript letters are significantly different $(\mathrm{p}<0.05)$.

\section{Cyanogenic glycosides}

Potential toxicity of cyanoglycosides arises from enzymatic degradation to produce hydrogen cyanide, resulting in acute cyanide poisoning. Cyanogenic glycosides are generally water soluble. During cooking, significant amounts of cyanogens are leached into cooking water. Several studies have reported increased reduction of cyanide in cooked products (Bolarinwa et al., 2016). This study demonstrated that heat treatments lead to a reduction in cyanogenic glycosides, with boiling $(0.18$ $0.38 \mathrm{mg} / 100 \mathrm{~g})$ being more effective than autoclaving $(0.39-0.72 \mathrm{mg} / 100 \mathrm{~g})$ (Figure 4). The overall cyanogenic glycoside content of the cultivars that were soaked had the highest concentration of hydrogen cyanide $(0.89-1.21 \mathrm{mg} / 100 \mathrm{~g})$. Boiled Fahari had the least number of cyanogenic glycosides $(0.18 \mathrm{mg} / 100 \mathrm{~g})$ present. Findings in a study by Onyeike and Omubo-Dede (2002) were in agreement with the results obtained. They found that cooked African yam bean (Sphenostylis stenocarpa) resulted in lower cyanogenic glucosides in samples that were autoclaved. A review conducted by Rawat et al. (2015), identified boiling/cooking as the heat processing technique to greatly reduce the content of cyanogenic glycosides as it causes the rupture of cell walls that leads to the contents of the cell to leak into the water. Umoren et al. (2008) found cooking to be more effective than autoclaving in reducing the hydrogen cyanide content. Udensi et al. (2007) found that boiled and autoclaved samples had a lower hydrogen cyanide content compared to raw samples. Autoclaving led to $87.58 \%$ and boiling led to $81.25 \%$ reduction in hydrogen cyanide in cowpea seeds.

\section{Oxalic acid}

Oxalic acid affects the metabolism of magnesium and calcium, while oxalates react with protein molecules to form complexes which inhibit peptic digestion. 
Autoclaved samples had the least amount of oxalic acid present $( \pm 2 \mathrm{mg} / 100 \mathrm{~g})$, boiled samples contained around ( $\pm 3-4 \mathrm{mg} / 100 \mathrm{~g})$ whereas soaked samples presented the highest concentration of oxalic acid ( $\pm 4 \mathrm{mg} / 100 \mathrm{~g}$ ) (Figure 5).

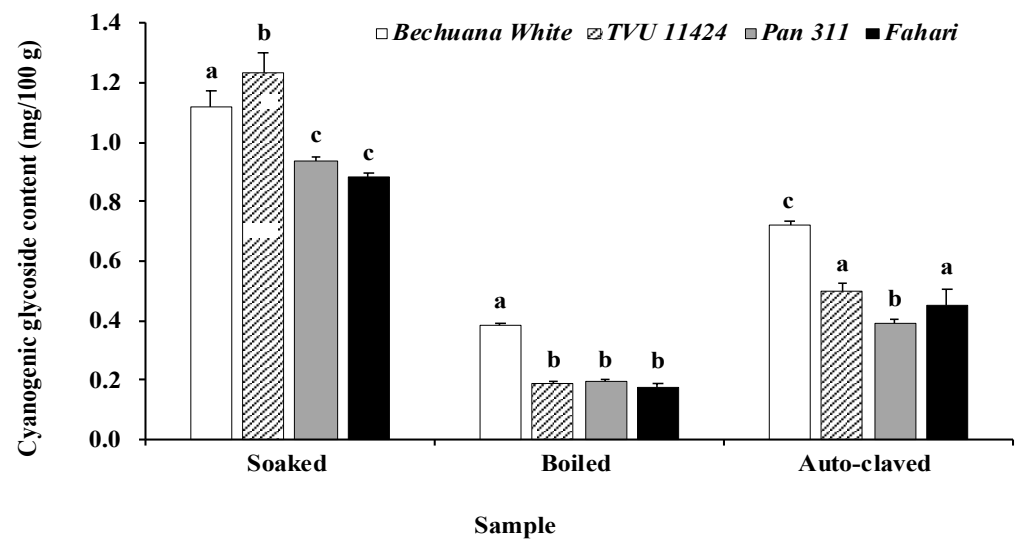

Figure 4. Effect of processing methods (soaked, boiled \& autoclaved) on cyanogenic glycoside content of cowpea cultivars, [Bars denote mean \pm standard deviation $(n=3)$ ]. Values with different superscript letters are significantly different $(p<0.05)$.

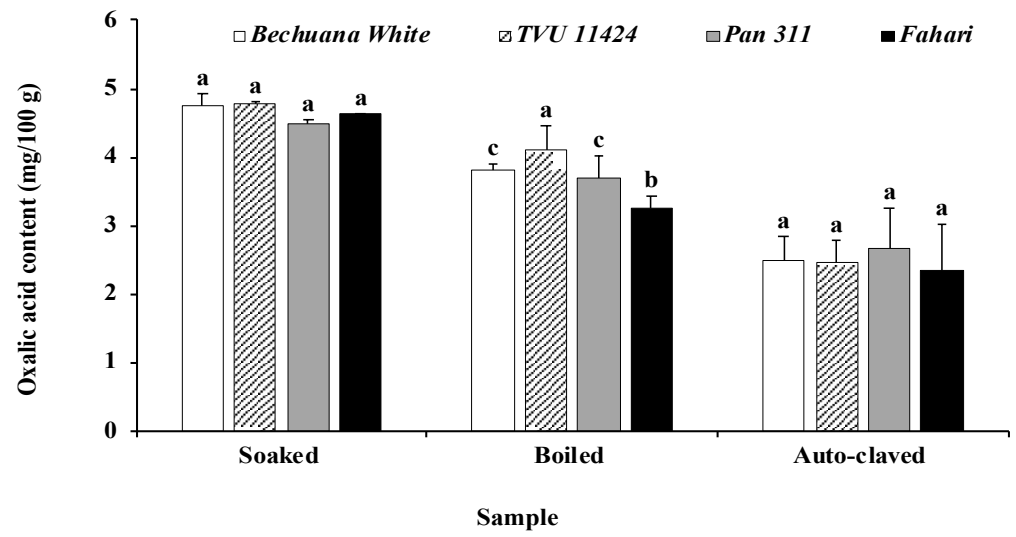

Figure 5. Effect of processing methods (soaked, boiled \& autoclaved) on the oxalic acid content of cowpea cultivars, Bars denote mean \pm standard deviation $(n=3)$. Values with different superscript letters are significantly different $(p<0.05)$.

It has been noted that boiling was not as effective in reducing oxalic acid as it was in reducing the other anti-nutritional factors. This could be attributed to the presence of water-soluble and water-insoluble oxalic acid. During the boiling procedure the water-soluble oxalic acid leached into the cooking water, while the water-insoluble oxalic acid formed complexes which were not removed. Thus, resulting in higher oxalic acid content than in autoclaving. Onyeike and OmuboDede (2002) found that cooking was more effective than autoclaving in reducing the oxalate content. Both processing methods allowed reducing the oxalate content 
of the raw sample. Moreover, Ihemeje et al. (2018) found boiling to be effective in reducing the oxalic acid content in the African yam bean and red kidney bean.

\section{Conclusions}

The nutritional significance of cowpea in human and animal diets suggests the needs for nutritional improvement through processing techniques to reduce the concentration of antinutritional factors in cowpea plants. Hence the results from the current study indicated that soaked cowpea samples had the lowest nutritional content and greatest anti-nutritional content. Boiling allowed for an improved protein content and was the most effective in reducing cyanogenic glycosides, phytic acid, tannins and trypsin inhibitors. While, autoclaving was the most effective in reducing the oxalic acid content based on the presence of waterinsoluble oxalic acid. It is concluded that the use of heat processes reduces the presence of anti-nutritional factors and thus precedes to an increased nutritional content.

\section{Acknowledgments}

The authors acknowledge the Durban University of Technology (Kwa-Zulu Natal, South Africa) and the National Research Foundation [Grant number 118134] for support.

\section{References}

Akande, K.E., Fabiyi, E.F. 2010. Effect of processing methods on some antinutritional factors in legume seeds for poultry feeding. International Journal of Poultry Science, $\mathbf{9}$, 996-1001.

Apata, D.F. 2008. Effect of cooking methods on available and unavailable carbohydrates of some tropical grain legumes. African Journal of Biotechnology, 7, 2940-2945.

Appoldt, Y., Raihani, G. 2017. Determining Moisture Content [online]. Available from: https://www.foodqualityandsafety.com/article/determining-moisture content/?singlepage $=1$ [accessed 20 March 2019].

Association of Official Analytical Chemists, Official Method of Analysis, AOAC, Washington (DC), 19th edition, 2012.

Bolarinwa, I.F., Oke, M.O., Olaniyan, S.A., Ajala, A.S. 2016. A review of cyanogenic glycosides in edible plants. Toxicology-New Aspects to This Scientific Conundrum.

Bora, P. 2014. Anti-nutritional factors in foods and their effects. Journal of Academia and Industrial Research, 3, 285-290.

Bressani, R., Sosa, J.L. 1990. Effect of processing on the nutritive value of Canavalia Jackbeans [Canavalia ensiformis (L)]. Plant Foods for Human Nutrition, 40, 207-214.

Deshpande, S.S., Cheryan, M. 1983. Changes in phytic acid, tannins, and trypsin inhibitory activity on soaking of dry beans (Phaseolus vulgaris L.). Nutrition Reports International, 27, 371-377.

Dhurandhar, N.V., Chang, K.C. 1990. Effect of cooking on firmness, trypsin inhibitors, lectins and cystine/cysteine content of navy and red kidney beans (Phaseolus vulgaris). Journal of Food Science, 55, 470-474. 
Drulyte, D., Orlien, V. 2019. The effect of processing on digestion of legume proteins. Foods, 8, 224.

El-Adawy, T.A. 2002. Nutritional composition and antinutritional factors of chickpeas (Cicer arietinum L.) undergoing different cooking methods and germination. Plant Foods for Human Nutrition, 57, 83-97.

FAO. 2018. Food and Agriculture Organization. Of the United Nation. http://www.fao.org/faostat/en/\#data. Accessed on 09 May 2020.

Gao, Y., Shang, C., Maroof, M.A., Biyashev, R.M., Grabau, E.A., Kwanyuen, P., Burton, J.W., Buss, G.R. 2007. A modified colorimetric method for phytic acid analysis in soybean. Crop Science, 47, 1797-1803.

Giami, S.Y. 1993. Effect of processing on the proximate composition and functional properties of cowpea (Vigna unguiculata) flour. Food Chemistry, 47, 153-158.

Hill, G.D. 2003. Plant antinutritional factors Characteristics ( $2^{\text {nd }}$ ed.) Academic Press: Washington, DC.

Ihemeje, A., Nwanekezi, E.C., Odimegwu, E.N., Ekwe, C.C. 2018. Effect of processing methods of toasting, soaking, boiling, sprouting on dietary fiber and antinutrient contents of African yam bean and kidney bean flour. European Journal of Food Science and Technology, 6, 40-48.

Inuwa, H.M., Aina, V.O., Gabi, B., Aimola, I., Toyin, A. 2011. Comparative determination of antinutritional factors in groundnut oil and palm oil. Advance Journal of Food Science and Technology, 3, 275-279.

Jéquier E. 1994. Carbohydrates as a source of energy. The American Journal of Clinical Nutrition, 59, 682s-685s

Naik, V.V., Patil, N.S., Aparadh, V.T., Karadge, B.A. 2014. Methodology in determination of oxalic acid in plant tissue: a comparative approach. Journal of Global Trends in Pharmaceutical Sciences, 5, 1662-1672.

Nell, F.J., Siebrits, F.K. 1992. Studies on the nutritive value of cowpeas (Vigna unguiculata). South African Journal of Animal Science, 22, 157-160.

Omenna, E.C., Olanipekun, O.T., Kolade, R.O. 2016. Effect of boiling, pressure cooking and germination on the nutritional and antinutrients content of cowpea (Vigna unguiculata). ISABB Journal of Food and Agricultural Sciences, 6, 1-8.

Omenna, E.C., Olanipekun, O.T., Kolade, R.O. 2016. Effect of boiling, pressure cooking and germination on the nutritional and antinutrients content of cowpea (Vigna unguiculata). ISABB Journal of Food and Agricultural Sciences, 6, 1-8.

Onwuka, G.I. 2005. Food analysis and instrumentation. Theory and Practice. Napthali Prints, 140-146.

Onyeike, E.N., Omubo-Dede, T.T. 2002. Effect of heat treatment on the proximate composition, energy values, and levels of some toxicants in African yam bean (Sphenostylis stenocarpa) seed varieties. Plant Foods for Human Nutrition, 57, 223231.

Rawat, K., Nirmala, C., Bisht, M.S. 2015. Processing techniques for reduction of cyanogenic glycosides from bamboo shoots. In 10th World Bamboo Congress, Korea.

Samtiya, M., Aluko, R.E., Dhewa, T., 2020. Plant food anti-nutritional factors and their reduction strategies: an overview. Food Production, Processing and Nutrition, 2, 1-14. 
Sathe, S.K., Deshpande, S.S., Salunkhe, D.K., Rackis, J.J. 1984. Dry beans of phaseolus. A review. Part 1. Chemical composition: Proteins. Critical Reviews in Food Science \& Nutrition, 20, 1-46.

Shi, L., Mu, K., Arntfield, S.D., Nickerson, M.T. 2018. Changes in levels of enzyme inhibitors during soaking and cooking for pulses available in Canada. J Food Sci Technol, 54, 1014-1022.

Slavin, J., Carlson, J. 1994. Carbohydrates. Advances in Nutrition, 5:760-761

Trugo, L.C., Donangelo, C.M., Trugo, N.M.F., Bach Knudsen, K.E. 2000. Effect of Heat Treatment on Nutritional Quality of Germinated Legume Seeds. Journal of Agricultural and Food Chemistry, 48, 2082-2086.

Trugo, L.C., Ramos, L.A., Trugo, N.M.F., Souza, M.C.P., 1990. Oligosaccharide composition and trypsin inhibitor activity of $P$. vulgaris and the effect of germination on the $\alpha$-galactoside composition and fermentation in the human colon. Food Chemistry, 36, 53-61.

Udedibie, A.B.I., Nwaiwu. 1988. The potential of jackbean (Canavalia ensformis) as animal feel. Nigerian. Agricultural. Journal, 23, 130-143.

Udensi, E.A., Ekwu, F.C., Isinguzo, J.N. 2007. Antinutrient factors of vegetable cowpea (Sesquipedalis) seeds during thermal processing. Pakistan Journal of Nutrition, 6, 194197.

Van Buren, J.P., Robinson, W.B. 1969. Formation of complexes between protein and tannic acid. Journal of Agricultural and Food Chemistry, 17, 772-777. 